\title{
Promotion of awareness and utilization of youth friendly service through multi- sectoral cooperation mechanism in China
}

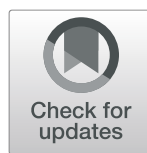

Ning Feng ${ }^{1} \mathbb{D}, \mathrm{Xi} \mathrm{Jin}^{2}$, Jiuling $\mathrm{Wu}^{2}$ and Linhong Wang ${ }^{3^{*}}$

\begin{abstract}
Background: Youth friendly services (YFS) was established in pilot areas in China. This study aimed to explore the promoting level on the awareness and utilization of YFS after the implementing of a multi-sectoral cooperation mechanism (MSCM) supported by social network theory (SNT) among multiple sectors related to young people reproductive health (YRH) closely.
\end{abstract}

Methods: A cross-sectional study with two separate self-administered questionnaire surveys was conducted before and after the implementing of a MSCM supported by SNT in both in-school and out-school unmarried young people aged 12-24 year-old in pilot areas in China. Both pre- and post- implementation surveys were conducted between December, 2008 and January, 2009, and between October, 2010 and January, 2011 respectively. The collected categorical data about the awareness on YFS in young people was described in percentage (\%). $X^{2}$ test was used to compare the differences between interventional and control areas, pre and after intervention, and changes in investigated areas after the intervention respectively. Binary logistic regression was used to analyze interventional effects after adjusting gender, in-school or out-school, and other factors. Significance level a was 0.05.

Results: The percentages of young people in interventional areas who could receive YRH education including that about YFS in schools, working sites and communities increased $(O R=15.485,6.166,3.723 ; 95 \%$ Cl: 2.939 4.715, 4.014 9.473, 11.421 20.994 respectively) statistically significantly $(P<0.05)$. The percentages of young people in interventional areas who "have heard of YFS clinic" and "know that YFS clinic has been established in local area" $(O R=9.325,11.244 ; 95 \%$ Cl: 7.433 11.699, 8.780 14.399 respectively), and knowledge rates on YFS manner and contents also increased $(O R=14.830,8.676 ; 95 \%$ Cl: 9.728 22.607, 5.175 14.548 respectively) statistically significantly $(P<0.05)$. The increments of knowledge rates on YFS price, time, hotline number, contents on contraception, pregnancy and sexual harass/violence were statistically significant $(P<0.05)$. The satisfaction degree on this service has also increased ( $O R=6.394,95 \%$ Cl: 2.789 14.655) statistically significantly $(P<0.05)$.

Conclusions: SNT is a helpful tool to facilitate the construction of an effective multi-sectoral cooperation mechanism to promote the awareness and satisfactory degree of YRH services.

Keywords: Youth friendly service, Awareness, Multi-sectoral cooperation, Reproductive health, Satisfactory degree

\footnotetext{
* Correspondence: profwanglinhong@163.com; linhong@chinawch.org.cn

${ }^{3}$ National Center for Non-communicable Disease Prevention and Control,

Chinese Center for Disease Control and Prevention, 27 Nanwei Road,

Xicheng District, Beijing, People's Republic of China

Full list of author information is available at the end of the article
}

(c) The Author(s). 2020 Open Access This article is distributed under the terms of the Creative Commons Attribution 4.0 International License (http://creativecommons.org/licenses/by/4.0/), which permits unrestricted use, distribution, and reproduction in any medium, provided you give appropriate credit to the original author(s) and the source, provide a link to the Creative Commons license, and indicate if changes were made. The Creative Commons Public Domain Dedication waiver (http://creativecommons.org/publicdomain/zero/1.0/) applies to the data made available in this article, unless otherwise stated. 


\section{Background}

Youth friendly service (YFS) is one of the most important public health strategies to promote reproductive health among young people in multiple aspects [1, 2]. It provides health-related information, health education and services regarding sexuality, contraception and sexually transmitted infections, including human immunodeficiency virus (HIV) infection. It also involves counseling young men about the importance of mutual respect towards decision of their female counterparts and their shared responsibility toward reproductive health $(\mathrm{RH})[3,4]$.

China started RH services for young people specially in 1990's and integrated them into the existing public infrastructure of adolescent health services. The service was improved according to international YFS guidelines $[1,2]$. YFS clinics were set up in public Maternal and Child Health $(\mathrm{MCH})$ Care Centres at county level. There was no research focus on the promotion of the utilization of YFS clinics specially and systematically before this study. However, several investigations had shown the needs of YFS in young people in these areas [5-9]. Also, the initial reports stated that the clinics faced challenges in their utilization and there was an obvious gap between low utilization degree of YFS clinic services and high demand for the services. Since then, the model has been improved constantly to create a friendly environment toward young people [4, 10-14]. There were 1.39538 billion people living in China main land in 2018 [15] among them $16.86 \%$ were young people aged $10-24$ year-old according to $0.824 \%$ sampling population survey conducted in 2017 [16]. Since young people are involved in various sectors across the country, a special multi-sectoral cooperation mechanism consisting of various sectors was established in pilot areas in 2008. In this study, we aimed to explore the level on promoting awareness and utilization of

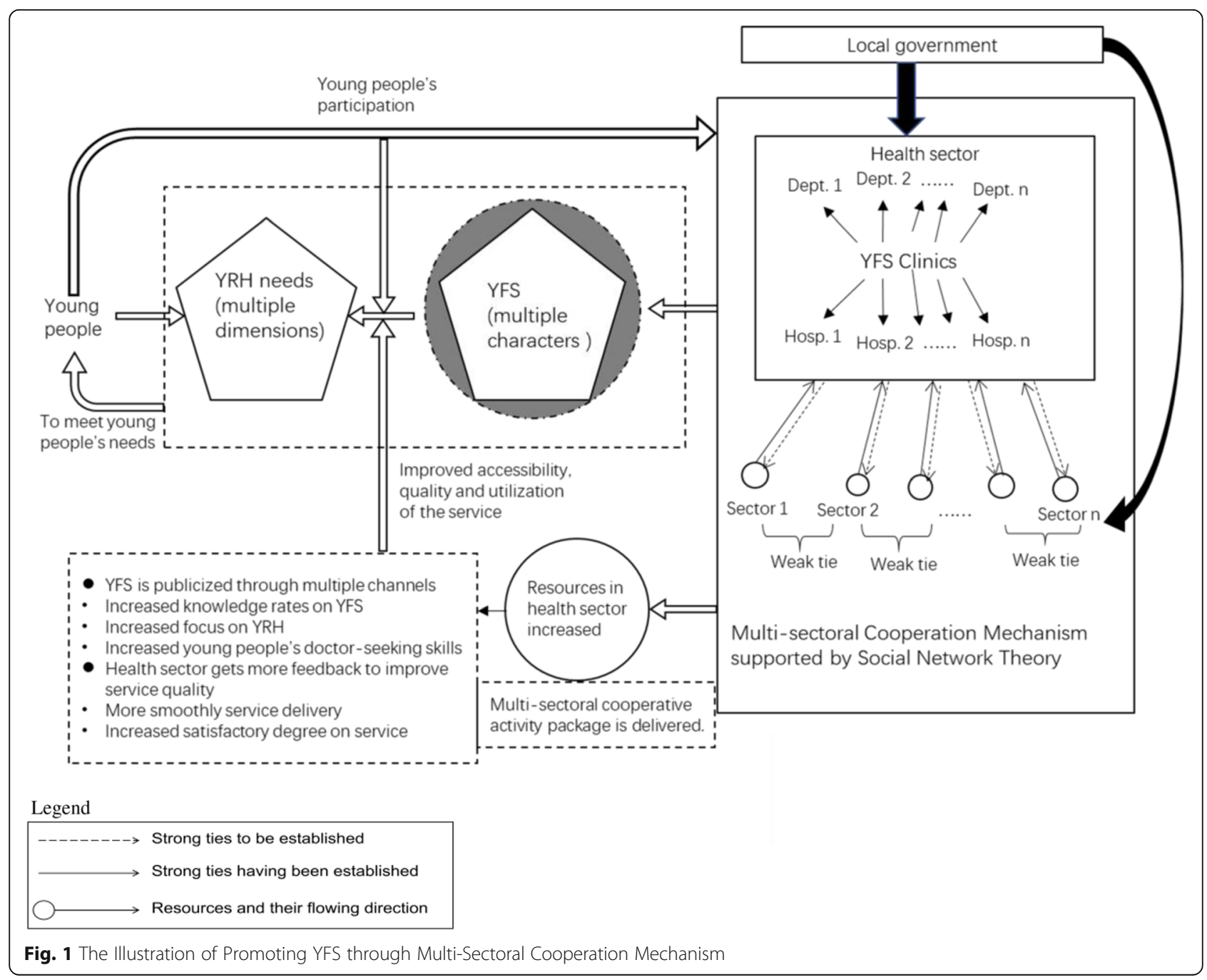




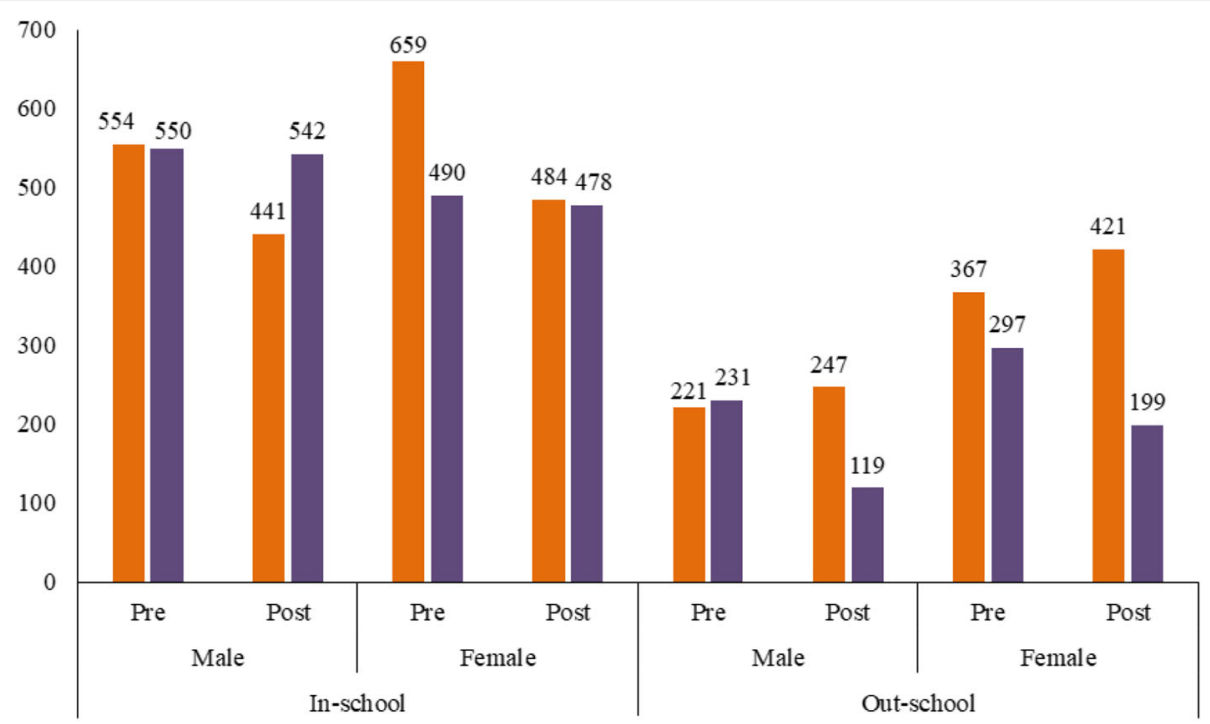

Legend

Intervention

Control

Fig. 2 Numbers of Young People Participating the Questionnaire Survey Pre and Post Intervention (cases)

YFS after implementing multi-sectoral cooperation mechanism.

\section{Methods}

\section{Study design}

This was a cross-sectional study with two separate surveys conducted before and after the implementation of multi-sectoral cooperation mechanism in pilot areas in China; pre-implementation survey was conducted between December, 2008 and January, 2009, and postimplementation survey between October, 2010 and January, 2011 in the same areas.

As a first stage, YRH project counties in Guangdong, Chongqing and Guizhou provinces were selected as

Table 1 Multi-Sectoral Cooperation Activities Developed by Using SNT

\begin{tabular}{|c|c|c|c|}
\hline SNT & MSCM & Actions & Activity Package \\
\hline $\begin{array}{l}\text { Emotional } \\
\text { intensity }\end{array}$ & $\begin{array}{l}\text { Common } \\
\text { causes }\end{array}$ & $\begin{array}{l}\text { Promote YFS utilization and } \\
\text { YRH }\end{array}$ & NA \\
\hline $\begin{array}{l}\text { Interaction } \\
\text { frequency }\end{array}$ & $\begin{array}{l}\text { Stakeholder } \\
\text { participation }\end{array}$ & $\begin{array}{l}\text { Guarantee the frequency of } \\
\text { coordination, communication } \\
\text { and cooperative activities }\end{array}$ & $\begin{array}{l}\text { For each year: } \\
\text { Twice multi-sectoral coordination meetings } \\
\text { - Once nation-level intensive training } \\
\text { - At least } 4 \mathrm{~h}^{\prime} \text { curriculum on YRH and YFS } \\
\text { - Twice lectures and Q\&A activities } \\
\text { - Regular publicity and lecture through various public media } \\
\text { - Twice feedbacks from young people on the services } \\
\text { - Once nation-level field technical supports } \\
\text { - Twice local self-assessments }\end{array}$ \\
\hline $\begin{array}{l}\text { Reciprocal } \\
\text { services }\end{array}$ & Confidence & $\begin{array}{l}\text { Interactive supports in } \\
\text { workforce, technique and } \\
\text { funding }\end{array}$ & $\begin{array}{l}\text { Multi-sectoral cooperative activities: } \\
\text { - Regular coordination meetings to discuss and resolve problems on } \\
\text { YRH and YFS } \\
\text { - Improvements on YFS facilities, environment and quality to absorb young people } \\
\text { - YRH education } \\
\text { - Trainings in multi-sectors including service providers Young people's feedback on } \\
\text { YFS } \\
\text { - Development and dissemination of various forms of IEC materials }\end{array}$ \\
\hline Intimacy & $\begin{array}{l}\text { Commitments/ } \\
\text { responsibilities }\end{array}$ & $\begin{array}{l}\text { Strength of interactive } \\
\text { supports }\end{array}$ & $\begin{array}{l}\text { Development and issuing of local administrative documents on MSCM to clarify } \\
\text { the role of each sector and cooperative activities } \\
\text { - Incorporation of each sector's performance in the cooperation into Annual Review } \\
\text { - Coordination by local government to ensure workforce, funding and materials needed } \\
\text { - Technical support and assessment to identify and resolve problems timely }\end{array}$ \\
\hline
\end{tabular}


implementation areas while those in Hei Longjiang, Shandong and Jiangsu provinces were selected as controls by matching the Gross Domestic Products (GDPs) between these counties. They were selected because YFS clinics had been established there and they were proactive to participate in the intervention and/or investigation.

As second stage, one junior and one high middle schools were selected randomly. One class was selected from each grade of both junior and high middle schools (3 junior and 3 high school classes), based on the similarity of the number of girls and boys. Students were recruited by their seat order into the study. If the classroom size was less than 40 , a class next to it was selected to recruit enough students.

For out-school young people enrollment, all unmarried young people aged 12-24 year-old from randomly selected communities or worksites in the investigated counties were included.

The investigated schools, communities and worksites for pre and post intervention were not the same.

\section{General setting}

China is the second-largest country by land area in the world and the most populous country, with a population more than 1.3 billion. The country is divided into 22 provinces, 5 autonomous regions, and 4 municipalities (Beijing, Tianjin, Shanghai and Chongqing) and 3 special administrative regions. Geographically, all provincial divisions can be grouped into 6 regions, including North China, Northeast China, East China, South Central China, Southwest China and Northwest China. The provinces are divided into prefectures, districts/counties, communities/townships, neighborhood committees/ villages (urban/rural).

\section{Multi-Sectoral cooperation mechanism}

The research team developed "Action Plan on Promoting the Delivery and Utilization of YFS through MultiSectoral Cooperation Mechanism" which was shared with the control areas after one and a half years of implementation in pilot areas.

Social network theory (SNT) was used to support the construction of the multi-sectoral cooperation mechanism. Originally, within the health sector, strong ties existed between YFS clinic and other departments as well as related medical institutions. So the exchange of information and resources between them were systematic and rich but superfluous. Other sectors related to YRH closely such as those of education, Women's Federation, the Communist Youth League, the media, community and China Youth Network (CYN) had less frequent interaction with the health sector but they

Table 2 Percentages of the Young People Who "Have heard of YFS clinic" in investigated areas (\%)

\begin{tabular}{|c|c|c|c|c|c|c|c|c|c|c|c|c|}
\hline \multirow{3}{*}{ Areas } & \multicolumn{4}{|c|}{ In-school } & \multicolumn{4}{|c|}{ Out-school } & \multicolumn{4}{|c|}{ Total } \\
\hline & \multicolumn{2}{|c|}{ Boys } & \multicolumn{2}{|c|}{ Girls } & \multicolumn{2}{|c|}{ Boys } & \multicolumn{2}{|c|}{ Girls } & \multicolumn{2}{|c|}{ Boys } & \multicolumn{2}{|c|}{ Girls } \\
\hline & $\begin{array}{c}\text { Pre- } \\
\text { interv. }\end{array}$ & $\begin{array}{l}\text { Post- } \\
\text { interv. }\end{array}$ & $\begin{array}{l}\text { Pre- } \\
\text { interv. }\end{array}$ & $\begin{array}{l}\text { Post- } \\
\text { interv. }\end{array}$ & $\begin{array}{c}\text { Pre- } \\
\text { interv. }\end{array}$ & $\begin{array}{l}\text { Post- } \\
\text { interv. }\end{array}$ & $\begin{array}{c}\text { Pre- } \\
\text { interv. }\end{array}$ & $\begin{array}{l}\text { Post- } \\
\text { interv. }\end{array}$ & $\begin{array}{c}\text { Pre- } \\
\text { interv. }\end{array}$ & $\begin{array}{l}\text { Post- } \\
\text { interv. }\end{array}$ & $\begin{array}{l}\text { Pre- } \\
\text { interv. }\end{array}$ & $\begin{array}{l}\text { Post- } \\
\text { interv. }\end{array}$ \\
\hline $\begin{array}{l}\text { Intervention } \\
\text { areas }\end{array}$ & $n=554$ & $n=441$ & $n=659$ & $n=484$ & $n=221$ & $n=247$ & $n=367$ & $n=421$ & $n=775$ & $n=688$ & $n=1026$ & $n=905$ \\
\hline $\begin{array}{l}\text { Tongliang, } \\
\text { Chongqing }\end{array}$ & 53.1 & 90.5 & 52.4 & $92.0^{*}$ & 58.5 & $96.5^{*}$ & 56.6 & $98.6^{*}$ & 54.6 & $92.7^{*}$ & 53.9 & $95.1^{*}$ \\
\hline Kaili, Guizhou & 22.1 & $81.6^{*}$ & 12.9 & $90.4^{*}$ & 47.8 & $80.3^{*}$ & 47.1 & $95.1^{*}$ & 29.4 & $81.1^{*}$ & 25.1 & $92.6^{*}$ \\
\hline $\begin{array}{l}\text { Huicheng, } \\
\text { Guangdong }\end{array}$ & 39.9 & $71.7^{*}$ & 22 & $78.9^{*}$ & 36.1 & $61.4^{*}$ & 26.9 & $81.5^{*}$ & 38.8 & $68.0^{*}$ & 23.8 & $80.1^{*}$ \\
\hline Control areas & $n=550$ & $n=542$ & $n=490$ & $n=478$ & $n=231$ & $n=119$ & $n=297$ & $n=199$ & $n=781$ & $n=661$ & $n=787$ & $n=677$ \\
\hline $\begin{array}{l}\text { Muling, } \\
\text { Hei Longiiang }\end{array}$ & 29.2 & $18.5^{*}$ & 26.8 & 19.6 & 38.7 & 36.5 & 36.4 & 36.8 & 32 & $21.7^{*}$ & 30.4 & $24.7^{*}$ \\
\hline Jimo, Shandong & 39.6 & $51.4^{*}$ & 24.7 & $56.4^{*}$ & 40 & $71.4^{*}$ & 35.9 & $91.9^{*}$ & 39.7 & $55.0^{*}$ & 28.9 & $66.8^{*}$ \\
\hline Yanhu, Jiangsu & 60.2 & $29.7^{*}$ & 56.1 & 29.9 & 59.3 & $81.5^{*}$ & 69.9 & 85.7 & 59.9 & $39.0^{*}$ & 61.3 & $46.3^{*}$ \\
\hline
\end{tabular}




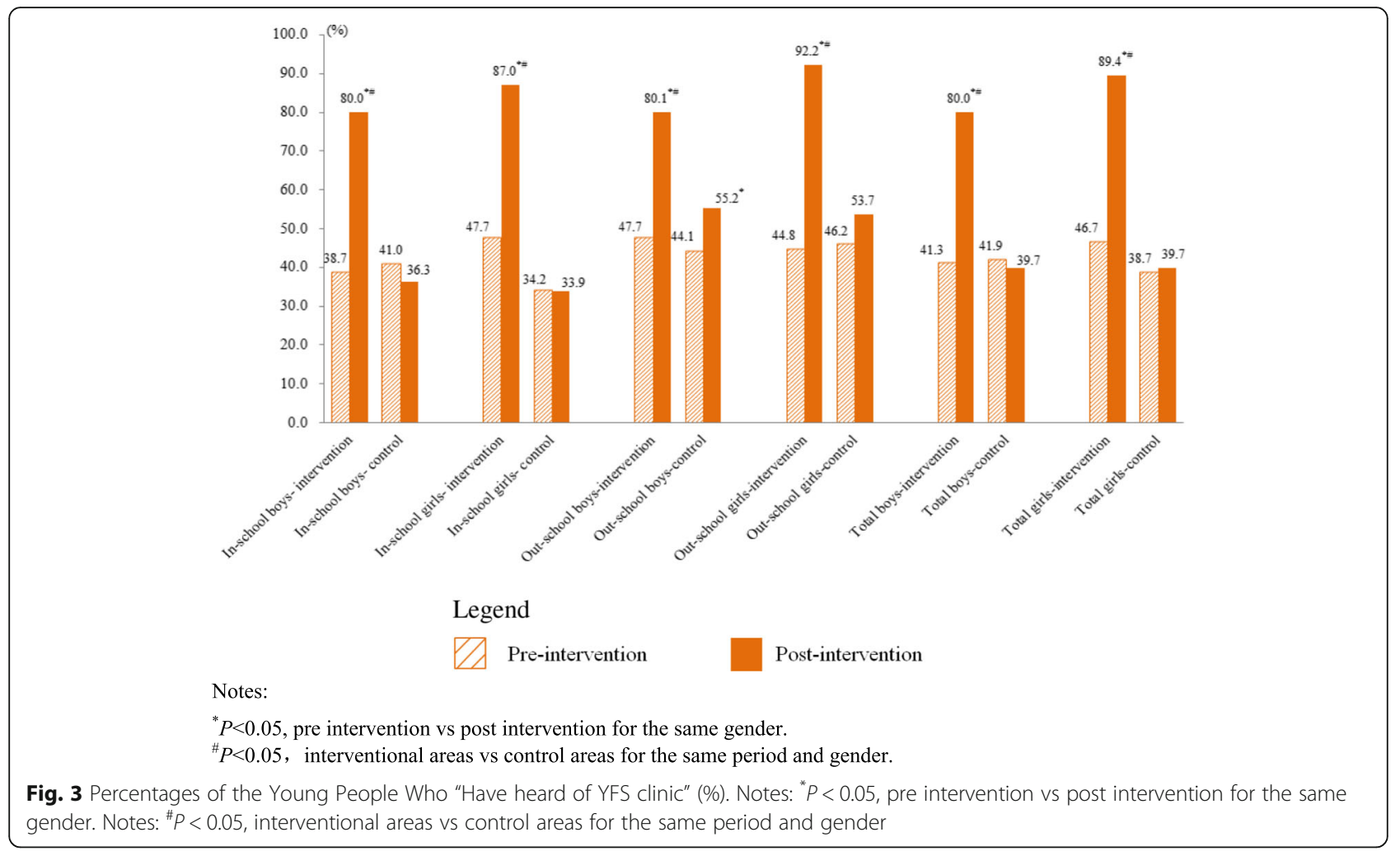

could provide new resources and information to the health sector. Then ties between health sector and other related sectors were strengthened through activities to construct a multi-sectoral cooperation mechanism in order to push the resources and information flow from these sectors to the health sector. No cooperation task was designed between sectors outside health sector in YRH (Fig. 1).

Based on the analysis of the resources in education, publicity, technique, facilities, materials and assistance

Table 3 Percentages of the Young People Who "Know that YFS clinic has been established in local area" in investigated areas (\%)

\begin{tabular}{|c|c|c|c|c|c|c|c|c|c|c|c|c|}
\hline \multirow{3}{*}{ Areas } & \multicolumn{4}{|c|}{ In-school } & \multicolumn{4}{|c|}{ Out-school } & \multicolumn{4}{|c|}{ Total } \\
\hline & \multicolumn{2}{|c|}{ Boys } & \multicolumn{2}{|c|}{ Girls } & \multicolumn{2}{|c|}{ Boys } & \multicolumn{2}{|c|}{ Girls } & \multicolumn{2}{|c|}{ Boys } & \multicolumn{2}{|c|}{ Girls } \\
\hline & $\begin{array}{c}\text { Pre- } \\
\text { interv. }\end{array}$ & $\begin{array}{c}\text { Post- } \\
\text { interv. }\end{array}$ & $\begin{array}{c}\text { Pre- } \\
\text { interv. }\end{array}$ & $\begin{array}{c}\text { Post- } \\
\text { interv. }\end{array}$ & $\begin{array}{c}\text { Pre- } \\
\text { interv. }\end{array}$ & $\begin{array}{c}\text { Post- } \\
\text { interv. }\end{array}$ & $\begin{array}{c}\text { Pre- } \\
\text { interv. }\end{array}$ & $\begin{array}{c}\text { Post- } \\
\text { interv. }\end{array}$ & $\begin{array}{c}\text { Pre- } \\
\text { interv. }\end{array}$ & $\begin{array}{c}\text { Post- } \\
\text { interv. }\end{array}$ & $\begin{array}{c}\text { Pre- } \\
\text { interv. }\end{array}$ & $\begin{array}{l}\text { Post- } \\
\text { interv. }\end{array}$ \\
\hline $\begin{array}{l}\text { Intervention } \\
\text { areas }\end{array}$ & $n=554$ & $n=441$ & $n=659$ & $n=484$ & $n=221$ & $n=\mathbf{2 4 7}$ & $n=367$ & $n=421$ & $n=775$ & $n=688$ & $n=1026$ & $n=905$ \\
\hline $\begin{array}{l}\text { Tongliang, } \\
\text { Chongqing }\end{array}$ & 31.1 & $86.4^{*}$ & 32.6 & $88.0^{*}$ & 52.4 & $81.8^{*}$ & 54.2 & $97.2^{*}$ & 37.2 & $85.1^{*}$ & 38.8 & $90.6^{*}$ \\
\hline Kaili, Guizhou & 10.2 & $88.6^{*}$ & 1.9 & $91.6^{*}$ & 41.1 & $96.6^{*}$ & 39.4 & $88.8^{*}$ & 19 & $90.9^{*}$ & 12.6 & $90.8^{*}$ \\
\hline $\begin{array}{l}\text { Huicheng, } \\
\text { Guangdong }\end{array}$ & 12.8 & $67.6^{*}$ & 6 & $74.7^{*}$ & 17.2 & $66.7^{*}$ & 12.2 & $84.2^{*}$ & 14.1 & $67.3^{*}$ & 7.8 & $77.4^{*}$ \\
\hline Control areas & $n=\mathbf{5 5 0}$ & $n=542$ & $n=490$ & $n=478$ & $n=231$ & $n=119$ & $n=\mathbf{2 9 7}$ & $n=199$ & $n=781$ & $n=661$ & $n=787$ & $n=677$ \\
\hline $\begin{array}{l}\text { Muling, } \\
\text { Hei Longjiang }\end{array}$ & 14 & 7.2 & 10.2 & 10.3 & 18.3 & 21.3 & 9.6 & 14.9 & 15.3 & $11.4^{*}$ & 10 & 11.7 \\
\hline Jimo, Shandong & 13.5 & $39.0^{*}$ & 4 & $49.6^{*}$ & 27.3 & $71.4^{*}$ & 21.4 & $89.2^{*}$ & 17.6 & $48.6^{*}$ & 9.1 & $61.3^{*}$ \\
\hline Yanhu, Jiangsu & 39.2 & $21.6^{*}$ & 42.9 & $14.7^{*}$ & 48 & $79.2^{*}$ & 54.4 & $82.9^{*}$ & 41.8 & 38.6 & 46.3 & $34.9^{*}$ \\
\hline
\end{tabular}

${ }^{*} P<0.05$, Pre intervention vs after intervention for the same gender

\# $P<0.05$, Interventional areas vs control areas for the same period and gender 
etc. that could be provided by various sectors, responsibilities of each sector in the cooperation were clarified; the 4 dimensions (emotional strength, interaction frequency, intimacy and reciprocity exchange) to judge the strength of ties in SNT were corresponded to the conditions to establish multi-sectoral cooperation. Next, cooperative activities were designed (Table 1) [17].

\section{Sample size calculation and sampling methods}

Assuming the prevalence of the knowledge rate on YFS clinic in young people in the study setting to be $10 \%$ with the significance level set at $5 \%$, and adjusting for a non-response of $10 \%, n=\left(\frac{U_{\alpha}}{\delta}\right)^{2} p(1-p)$ was used to calculate and the smallest needed sample size was 554. A stratified (schooling going versus out-of-school) multi-stage sampling strategy was used to achieve the required sample. For schooling going adolescents, the first stage sampling unit included counties or districts while the second sampling unit was school and the third stage students selected from each school. While, for out-school young people, the communities and enterprises that were willing to attend the survey and for which it was easy to organize young people were selected to recruit as many young people as possible. The reason for difference in recruitment method of inschool and out-school participants is because schooling young people were easier to organize than those of out-school ones. Before intervention, a total of 3369 young people were recruited from 12 schools ( 2 of each area), 9 communities and 15 enterprises. After intervention, 2931 young people were recruited from 12 schools (2 of each area), 5 communities and 19 enterprises (Fig. 2).

\section{Data collection}

Investigator trainings were conducted before the surveys. Two fixed investigators along with two CYN members (one male and one female) conducted the surveys. The research team also conducted supervised technical support in implementation areas to ensure good quality implementation and services. The questionnaire was designed to understand the knowledge level on the existence of local YFS clinic, its services, and young people's satisfaction level on it. The participants completed the self-administered questionnaires independently, and informed consent was taken before the administration of the survey. Although both questionnaire and group discussion were carried out for the whole study, this paper only reported the questionnaire part.

\section{Statistical analysis}

The data collected was double-entered with validation using Epidata Entry version 3.1 and exported into Statistical Package for Social Science (SPSS) 11.5 for data analysis. The collected categorical data

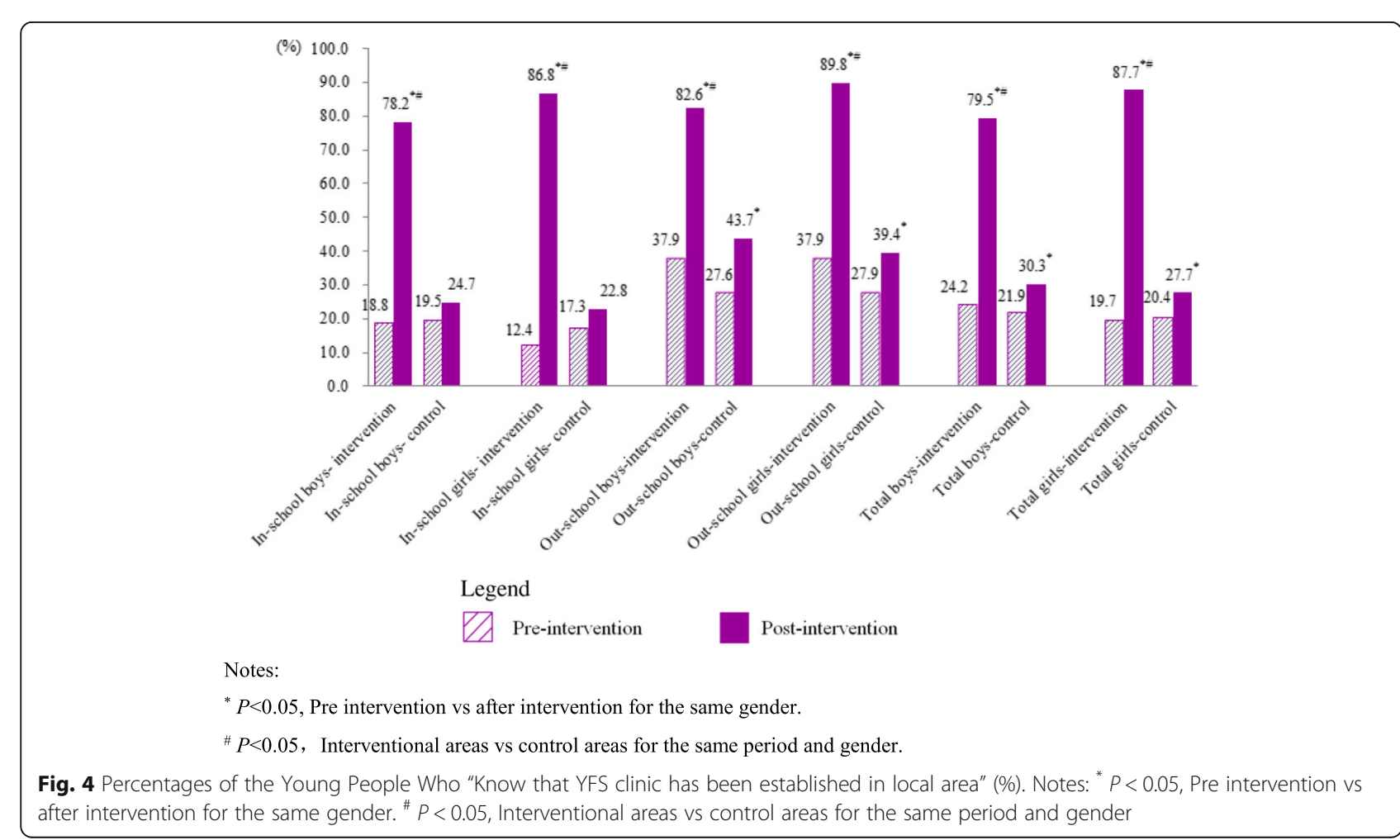


was described with percentage (\%) and chi-square test was used to compare the differences between interventional and control areas. Logistic regression was used to determine the association between the intervention (exposure variables) and knowledge level as well as satisfactory degree (outcome variables). Unadjusted odd ratios with 95\% Confidence Interval were calculated and those variables with $p$ value less than 0.2 were included in the multivariate model. Significance level $\alpha$ was set to be 0.05 .

The statistically significant increasing of knowledge level on the existence of local YFS clinic, its service characters and contents, and young people's satisfaction degree on it when compared with the control group were considered as interventional effects in this study.

\section{Results}

Before intervention, a total of 3369 young people were recruited with mean ages of 15.8 and 20.8 years for in-school and out-school ones respectively. After intervention, a total of 2931 young people with mean ages of 15.9 and 21.2 years for in-school and out-school ones respectively. The difference for out-school young people was less than natural increment of age (1.5 years) $(\mathrm{t}=4.684, P<0.05)$.

\section{Young people's knowledge rates on YFS clinics}

Before intervention, there was no statistically significant difference in the rates of "Have heard of YFS clinic" between interventional and control areas $(P>0.05)$. After intervention, this rate increased obviously in all 3 interventional areas and higher statistically significantly $\left(\mathrm{X}^{2}\right.$ in-school male $=386.244, X^{2}$ in-school female $=274.255, X^{2}$ out-scholl male $=23.448, \chi^{2}$ out-school female $=167.768, P$ values $\left.<0.05\right)$ than that of the 3 control areas in total for the same type and gender of young people (Table 2, Fig. 3).

Before intervention, there was no statistically significant differences in the percentages of young people who "Know that YFS clinic has been established in local area" $(P>0.05)$. After intervention, the percentages in all 3 interventional areas increased obviously, and higher statistically significantly than those of young people with the same type (in-school or out-school) and gender respectively in control areas $\left(X^{2}\right.$ in-school male $=355.920$, $X^{2}$ in-school female $=3520.270, \quad X^{2}$ out-school male $=101.397$, $X^{2}$ out-school female $\left.=198.591, P<0.05\right)($ Table 3, Fig. 4).

\section{Knowledge rates on manner and content of YFS}

After intervention period, among the young people who "Know that YFS clinic has been established in local area",

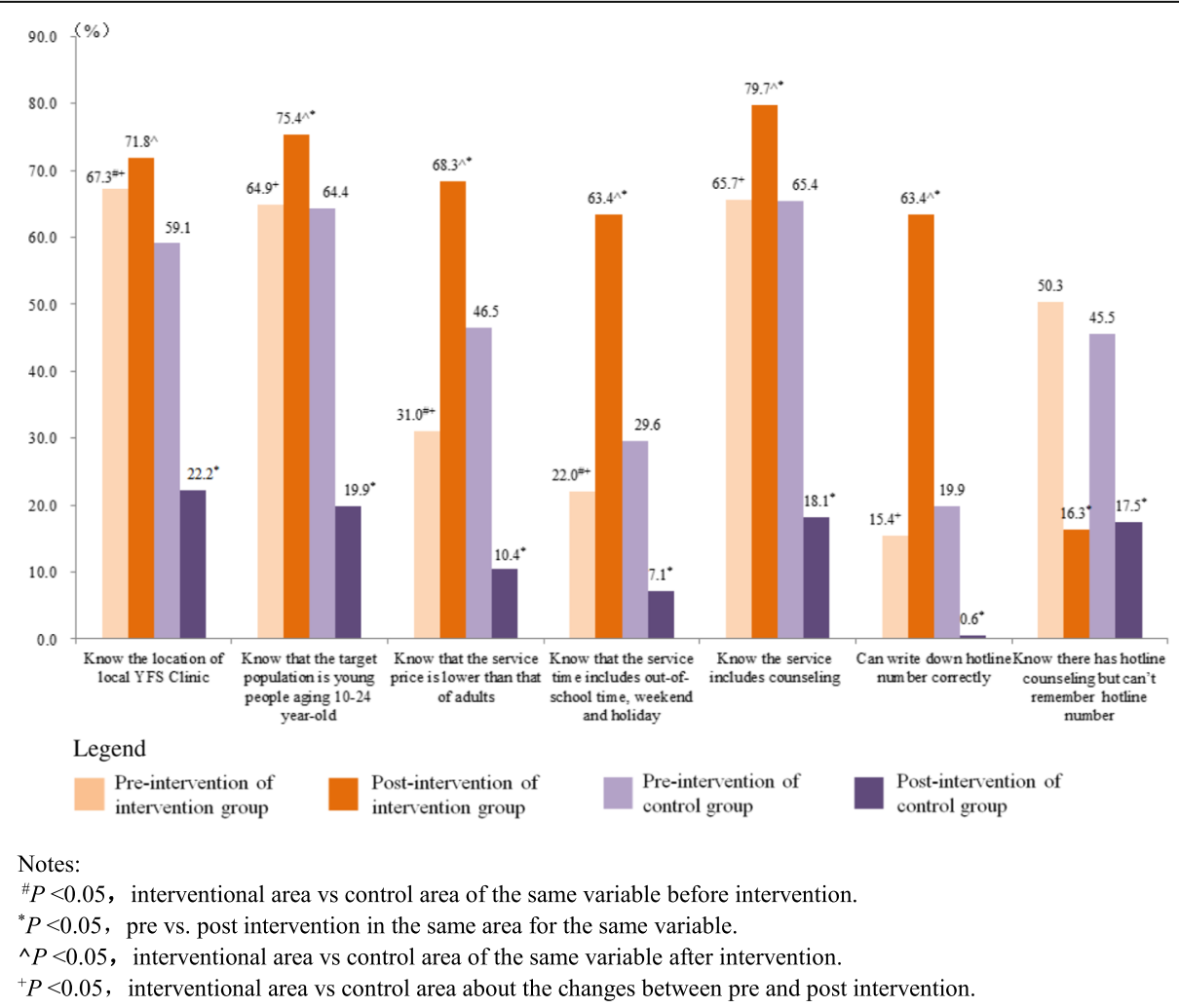

Fig. 5 Knowledge Rates on Manner of YFS among Young People "Knowing that YFS clinic has been established in local area"(\%). Notes: ${ }^{\#}<<0.05$, interventional area vs control area of the same variable before intervention. ${ }^{*} P<0.05$, pre vs. post intervention in the same area for the same variable. $\wedge P<0.05$, interventional area vs control area of the same variable after intervention. ${ }^{+} P<0.05$, interventional area vs control area about the changes between pre and post intervention 
most of knowledge rates on YFS manner and content increased in interventional areas but decreased in control areas statistically significantly $(P<0.05)$ although 4 knowledge rates in control areas were higher than those in interventional with statistical significances $(P<0.05)$ before interventional period. The increment values in the knowledge rates on the prices, time, hotline number, contraception, pregnancy and sexual harass/violence of contents of YFS were larger comparatively (Fig. 5, Fig. 6).

\section{The relationship between the intervention and the} improvement of knowledge and satisfaction degrees

Knowing at least 4 of 5 characters including site, target population, time and price, hotline number of YFS clinic was seen as knowing service manner. Knowing at least 9 of 12 content variables was seen as knowing service contents. The Binary logistic regression analysis on intervention-control grouping and pre-post intervention showed that the increment of knowledge and satisfaction degrees on the services have statistically significantly closely relationships with the intervention $(P<0.05)$ (Fig. 7).

\section{Discussion}

The study which is an ecology-like one showed that the multi- sectoral cooperation intervention had improved both knowledge and satisfactory degrees on YFS effectively in young people. The increasing of knowledge degree on YFS manner $(P<0.05, O R=14.830,95 \% \mathrm{CI}$ : 9.728 22.607) and local YFS clinic $(P<0.05, \quad O R=$ 11.244, 95\% CI: $8.780 \sim 14.399)$ had the closest relationship with the intervention $(P<0.05)$. In another paper

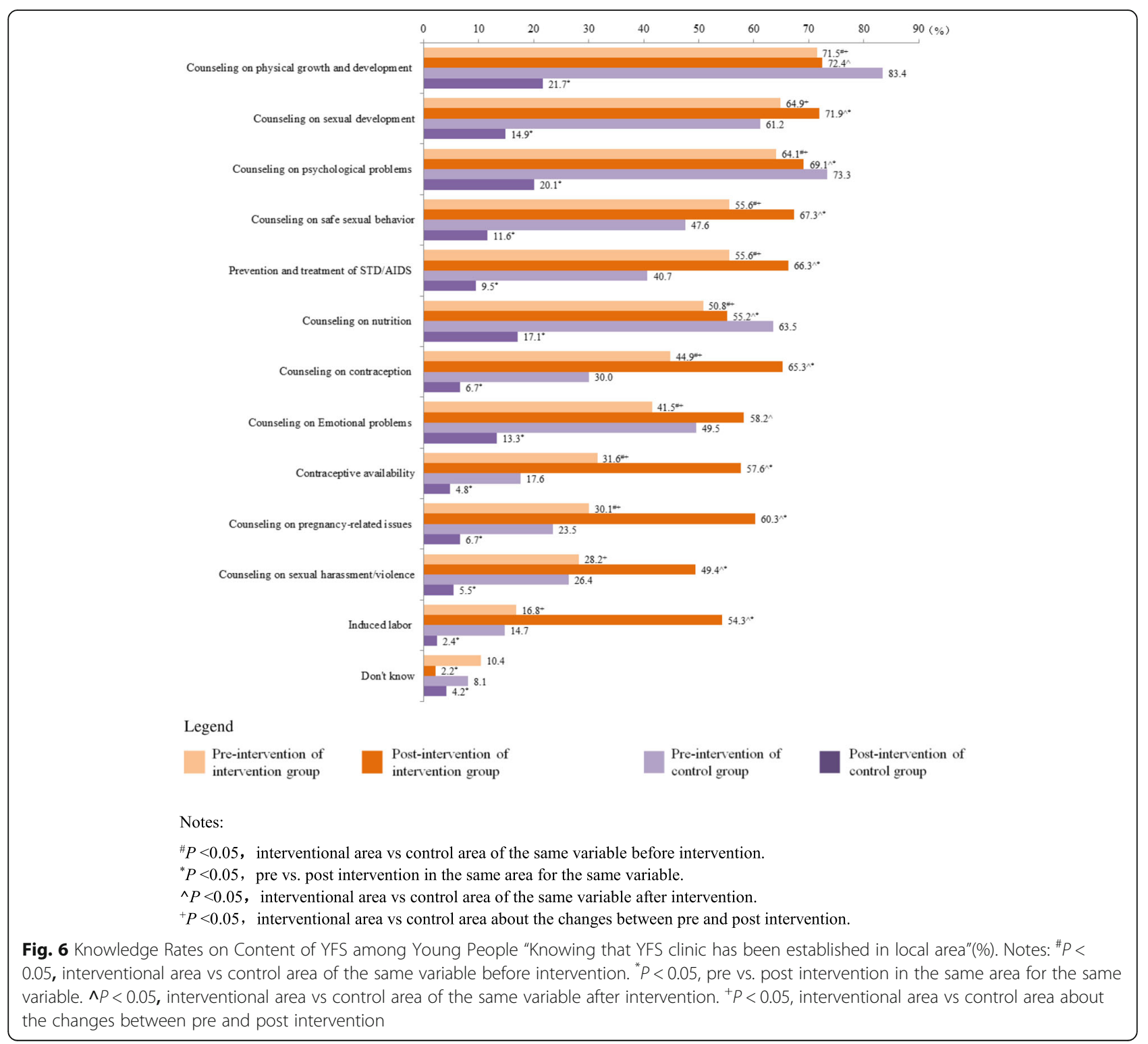




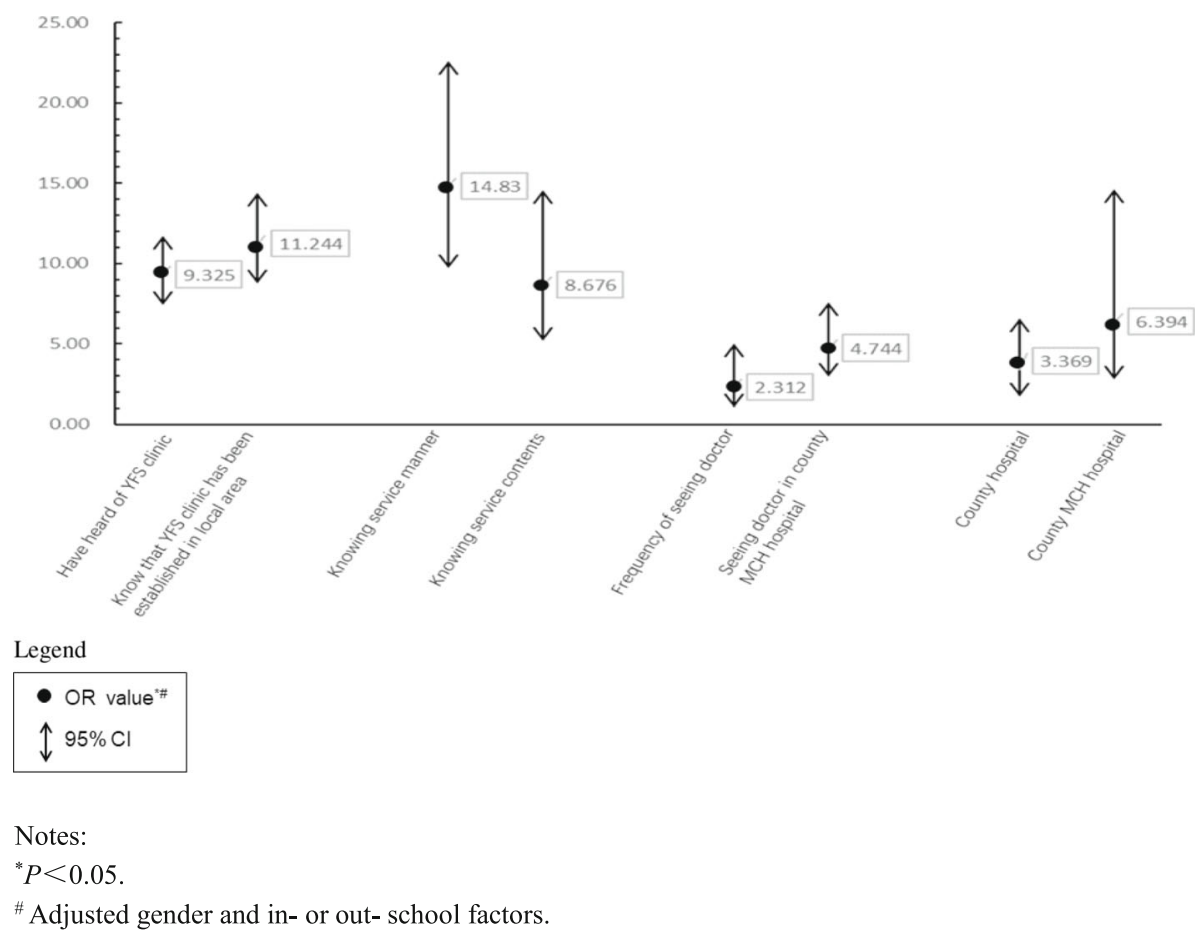

Fig. 7 Binary Logistic Regression Analysis on the Effect of Intervention. Notes: ${ }^{*} P<0.05$. \# Adjusted gender and in- or out- school factors

about this study, the service quality in interventional areas increased considerably for more than twice of that before intervention while only no more than once in control areas in total [18]. This dominates that the utilization on the service has been improved finally. Maybe the deepened understanding on YFS was helpful for YFS' multiple characters to inosculate multiple needs of young people in $\mathrm{RH}$, thus it is a beneficial basis to generate good interaction between young people and the services which increase the opportunity to utilize the service by young people. However, in control areas that had not received systematic intervention, even the rates about "Knowing that service price is lower than that of adults", "Knowing the service includes counseling on physical development, psychological problems and nutrition" etc. were better than those interventional areas before intervention period, they became worse after the intervention period which was showed in all groups of young people and more obvious in in-school group. So, the multi-sectoral intervention in a planned way just after the establishment of YFS to improve the awareness and utilization on YFS may produce a positive effect.

Several studies showed that outreach activities and social mobilization that put health education as priority were quite effective to promote the utilization of YFS or even more effective than service delivery itself, although some researches did not show statistically significant differences or set up control [19-22]. While, by an intervention with control, we established a structured multi-sectoral mechanism to deliver not only services but also health education on YFS in young people as well as create supportive public environment, and obtained a positive output. The education on YFS is also a critical way to provide $\mathrm{RH}$ information and education.

Some study said that service provider's attitude on YFS affected its utilization: positive attitude is beneficial to the utilization, while negative attitude is the barrier and even slower the reducing of sexual transmitted infection and un-wanted pregnancy [23]. The strengthened relationship on YRH between service providers and other sectors through multi-sectoral cooperation mechanism including young people's participation might improve the attitudes of service providers on YFS which also did good to the utilization. So, the construction of a special multi-sectoral cooperation mechanism to promote the delivery and utilization of YRH service can be considered as an important component of YFS. It is suggested to master the construction skills by YFS providers during the planning of YFS, and the skills should be strengthened continuously through capacity building. Service providers need to be skillful in not only providing correct information to young people through both effective interpersonal communications and regular population education, but also advocating government, identifying and organizing multi-sectors, clarifying responsibilities and strengthening cooperation to create a good social environment for YFS utilization.

In this study, the knowledge rates in out-school young people of two control areas increased statistically 
significantly. Some studies showed that out-school young people had more risk behaviors in $\mathrm{RH}$ than inschool ones so that they had stronger needs for $\mathrm{RH}$ service [24, 25]. So, out-school young people paid more attention on YFS perhaps. The detailed reasons need to be explored by further investigation. Whether the increasing of their knowledge degree on YFS through effective intervention be helpful to promote their knowledge degree on pre-marriage and maternity health care services can be proved by further follow-up investigation.

\section{Conclusions}

Social network theory is a helpful tool to facilitate the construction of an effective multi-sectorial cooperation mechanism to promote the awareness and satisfactory degree of YRH services. The results above are important references to guide establishment of multi-sector cooperation mechanisms in the field of young people reproductive health promotion or even public health to coordinate each sector's role in the cooperation framework aiming to intervention objectives as well as overcome related obstacles and weaknesses in multi-sectoral cooperation.

\section{Abbreviations}

CYN: China Youth Network; GDPs: Gross Domestic Products; MCH: Maternal and Child Health; RH: Reproductive health; SNT: Social network theory;

YFS: Youth friendly services; YRH: Young people reproductive health

\section{Acknowledgements}

The authors wish to thank all the middle young people and their schools and enterprises who participated in this study and the research assistants. We also acknowledge YFS clinic service providers that participated the study.

\section{Authors' contributions}

$\mathrm{FN}$, has engaged in the design of the study and collection, analysis, and interpretation of data and writing the manuscript. WLH, has engaged the technical support to the interpretation of data and writing the manuscript. $J X$, has engaged in the technical support to the design of the study and collection, analysis, and interpretation of data. WJL, has engaged in the technical support to the design of the study and collection of data. All authors have read and approved the manuscript, and ensure that this is the case.

\section{Funding}

The source of funding for the research reported comes from United Nations Population Fund Operational Research in Reproductive Health funding CHN51B603. The funding body has financially supported the design of the study and collection, analysis, and interpretation of data and in writing the manuscript should be declared.

\section{Availability of data and materials}

All data generated or analyzed during this study are included in this published article.

\section{Ethics approval and consent to participate}

This study was conducted according to the guidelines laid down in the Declaration of Helsinki. The nature of the study was explained to the investigated young people prior to their participation. The young people's participating of the study in the investigation is regarded as informed consent which has been noted at the beginning of the questionnaire. There was a written expression on the title page of the questionnaire as: Participation in the questionnaire is voluntary, can be suspended at any time. Young people who didn't agree with the questionnaire would quit on their own. Parental consent has been obtained. There is no biological sample collected from the young people who participated the questionnaire survey, neither individual information nor its correlation with the answers was publicized, data analysis focused on population but not the individual perspective. This social investigation was carried out in schools, communities and enterprises, but not in hospitals. In China, there is no related provision to require that sociological survey study should go through ethics review. So, the ethics committee's approval on the study was not mandatory when the study was conducted in 2010.

\section{Consent for publication}

Not applicable.

\section{Competing interests}

The authors declare that they have no competing interests.

\section{Author details}

${ }^{1}$ Center for Global Public Health, Chinese Center for Disease Control and Prevention, Room 211, 155 Changbai Road, Changping District, Beijing, People's Republic of China. ${ }^{2}$ National Center for Women and Children's Health, Chinese Center for Disease Control and Prevention, 12 Dahuisi Road, Haidian District, Beijing, People's Republic of China. ${ }^{3}$ National Center for Non-communicable Disease Prevention and Control, Chinese Center for Disease Control and Prevention, 27 Nanwei Road, Xicheng District, Beijing, People's Republic of China.

Received: 25 August 2019 Accepted: 3 February 2020

Published online: 24 May 2020

\section{References}

1. World Health Organization: Adolescent friendly health services: An agenda for change. Geneva; 2002.

2. World Health Organization. Strengthening the health sector response to adolescent health and development. Geneva; 2009. p. 3-6.

3. United Nations. International conference on population and development. Cairo; 1994.

4. International Planned Parenthood Federation. Provide: strengthening youth friendly services. London; 2008.

5. Wu Q, Tian XB, Wu JL, et al. The attitude of rural adolescents to the establishment of adolescent health clinic. Maternal Child Health Care China. 2008;12:52-4.

6. Ma YT, Yu XM, Wei W, et al. Analysis on the utilization and influencing factors of reproductive health services in male adolescents. Chin J Child Health. 2008;16(4):152-4

7. Shi XY, Yu XM, Duan CM, et al. Study on the factors of the utilization of HIV/ AIDS prevention and control services among out-school adolescents. Modern Preventive Med. 2007;34(11):2031-3.

8. $Y u X M, L i Y$, Gong $L X$, et al. Discussion and on adolescent friendly reproductive health service mode and the evaluation of its effect. Chin J Reproductive Health. 2005;16(3):154-8.

9. Yu XM, Zhang JC, et al. Analysis of willingness and influencing factors of adolescent reproductive health service seeking in adolescent of 4 cities in China. Chin J Preventive Med. 2004;5(5):333-6.

10. Di JLWQ, Wang $L H$, et al. Demand investigation on adolescent health care clinic service contents. Chin J MCH Res. 2008;19(4):319-21.

11. Godia PM, Olenja JM, Lavussa JA, et al. Sexual reproductive health service provision to young people in Kenya; health service providers' experiences. BMC Health Serv Res. 2013;13:476-87.

12. Chandra-Mouli V, Mapella E, John T, et al. Standardizing and scaling up quality adolescent friendly health services in Tanzania. BMC Public Health. 2013;13:579-84.

13. Godia PM, Olenja JM, Hofman JJ, et al. Young people's perception of sexual and reproductive health services in Kenya. BMC Health Serv Res. 2014;14: $172-83$

14. Geary RS, Gómez-Olivé FX, Kahn K, et al. Barriers to and facilitators of the provision of a youth-friendly health services programme in rural South Africa. BMC Health Serv Res. 2014;14:259-65.

15. National Bureau of Statistics of China. Statistical Bulletin on National Economic and Social Development. Beijing: China Statistics Press; 2018.

16. National Bureau of Statistics of China. China Statistical Yearbook. Beijing: China Statistical Publishing House; 2018. 
17. Feng N, Wang LH. A multi-sectoral cooperation mechanism supported by social network theory to promote the utilization of youth friendly service. J Chin School Health. 2018;39(5):644-8.

18. Feng $\mathrm{N}$, Jin $\mathrm{X}$, Yang $\mathrm{Q}$, et al. Intervention research on the promotion of the utilization about YFS through multi-sectoral cooperation. J Chin School Health. 2015;36(2):177-81.

19. Kesterton AJ, de Mello MC. Generating demand and community support for sexual and reproductive health Services for Young People: a review of the literature and programs. Reprod Health. 2010;7:25-35.

20. Pande R, Kurz K, Walia S, et al. Improving the reproductive health of married and unmarried youth in India. Washington, DC: International Center for Research on Women; 2007

21. Speizer IS, Kouwonou K, Mullen S, et al. Evaluation of the ATBEF youth Centre in Lome, Togo. Afr J Reprod Health. 2004;8(3):38-54.

22. Kabir H, Saha NC, Wirtz AL, et al. Treatment-Seeking for Selected Reproductive Health Problems: Behaviours of Unmarried Female Adolescents in Two Low-Performing Areas of Bangladesh. Reproductive Health. 2014;11:54-9.

23. Tilanhun M, Mengistie B, Egata G, et al. Health workers' attitudes toward sexual and reproductive health services for unmarried adolescents in Ethiopia. Reprod Health. 2012;9:19-24.

24. Negeri EL. Assessment of risky sexual behaviors and risk perception among youths in Western Ethiopia: the influences of family and peers: a comparative cross-sectional study. BMC Public Health. 2014;14:301-11.

25. Embleton L, Wachira J, Kamanda A, et al. "Once you join the streets you will have to do it": sexual practices of street children and youth in Uasin Gishu County, Kenya. Reprod Health. 2015;12:106-16.

\section{Publisher's Note}

Springer Nature remains neutral with regard to jurisdictional claims in published maps and institutional affiliations.

Ready to submit your research? Choose BMC and benefit from:

- fast, convenient online submission

- thorough peer review by experienced researchers in your field

- rapid publication on acceptance

- support for research data, including large and complex data types

- gold Open Access which fosters wider collaboration and increased citations

- maximum visibility for your research: over $100 \mathrm{M}$ website views per year

At BMC, research is always in progress.

Learn more biomedcentral.com/submissions 